\title{
Measurements of Nitric Oxide and Peroxynitrite
}

\section{Hideharu Shintani*}

Chuo University, School of Science, 1-13-27, Kasuga Bunkyo 112-0003 Tokyo, Japan

Keywords: Nitric Oxide; Peroxynitrite; Measurement; Macrophage

\section{Introduction}

Although there is much interest in NO (nitric oxide) and peroxynitrite (OONO), their measurement in biological media is difficult because of their short lifetimes and low concentrations. Here, the use of an NO-sensitive electrode is first described for direct realtime measurement of NO in endothelial cells. A method for detecting peroxynitrite produced by the macrophage is also given. Brief references to other methods are included in the comments sections.

\section{NO measurement with NO-sensitive electrodes}

Calibration [1]

\section{Protocol}

1. Prepare KH solution (HEPES-buffered modified KrebsHenseleit solution), containing $\mathrm{NaCI}(137 \mathrm{mM})$, KCI (1.1 $\mathrm{mM}), \mathrm{CaCI}_{2} \cdot 2 \mathrm{H}_{2} \mathrm{O}(0.18 \mathrm{mM}), \mathrm{MgCI}_{2} \cdot 6 \mathrm{H}_{2} \mathrm{O}(0.1 \mathrm{mM})$, $\mathrm{NaHCO}_{3}(4.2 \mathrm{mM})$, glucose $(5.6 \mathrm{mM})$, and HEPES $(5 \mathrm{mM})$. After addition of optional reagents adjust $\mathrm{pH}$ to 7.4 with $\mathrm{NaOH}$ $(0.1 \mathrm{M})$.

2. Immerse $\mathrm{NO}$ electrode in $\mathrm{KH}$ solution $(20 \mathrm{~mL})$ and read basal current after stabilization.

3. Immerse NO electrode in freshly prepared SNAP solution (1 $\mathrm{mM}, 20 \mathrm{~mL}$ ) and read NO current after stabilization (waiting for ca $5 \mathrm{~min}$ )

4. Repeat steps 2 and 3 three times and calculates mean NOdependent current.

Although calibration of the electrode can be performed with authentic NO solution, this calibration is not practical because it is difficult and troublesome to maintain the buffer solution anaerobic; and the concentration of authentic NO solution should be determined by other methods, e.g. the oxyhaemoglobin method [2].

\section{Comments}

1. NO measurements can be performed with an NO monitor (NO-501, lnter Medical, Japan) with an NO-sensitive electrode (NOE-47, $200 \mathrm{~mm} \varphi$, Inter Medical, Japan), or with an isolated nitric oxide meter (ISO-NO Mark II, World Precision Instruments, USA) with an NO sensor (ISO-NOP 200, World Precision Instruments, USA). All experiments must be performed with electromagnetic shields, made of an iron mesh screen, to avoid external noise. Plastics which are easily charged with electricity can cause unexpected noise.

2. New electrodes (both working and counter electrodes from Inter Medical) should be immersed for one day in buffer solution before use. It takes more than $30 \mathrm{~min}$ to stabilize basal current after first connecting the electrode and turning on the NO monitor. The electrodes are stored with the tips immersed in the buffer.

\section{The Measurement of NO Produced by Endothelial Cells \\ Protocol}

1. Perfuse bovine aortic endothelial cells confluently cultured on a cover slip $(15 \mathrm{~mm} \varphi)$, with $\mathrm{L}$-arginine solution ( $\mathrm{L}$-arg, $\mathrm{MW}=$ 174.2, $50 \mu \mathrm{M})$.

2. Place NO electrode as close as possible to the cover slip without making contact. Start recording the basal level of electrode current and wait until the current has stabilized (ca $30 \mathrm{~min}$ ).

3. Switch the perfusate to $1 \mathrm{mM} \mathrm{ATP} / 50 \mathrm{mM} \mathrm{L}$-arg solution to stimulate endothelial cells. ATP $(\mathrm{Mr}=551)$ should be stored at $-20^{\circ} \mathrm{C}$.

4. Re-switch the perfusate to $50 \mu \mathrm{M}$ L-arf solution and confirm that the current returns to the basal level.

\section{Comments}

1. Use a perfusion system as shown in Figure 1. It is important to use a hydrostatic pressure of $\mathrm{ca} 40 \mathrm{~cm} \mathrm{H}_{2} \mathrm{O}$ so that the flow is constant, because fluctuations of the flow rate cause noise on the electrode current. All perfusate should be prepared by dissolving reagents in $\mathrm{KH}$ solution and adjusting the $\mathrm{pH}$ to 7.4 .

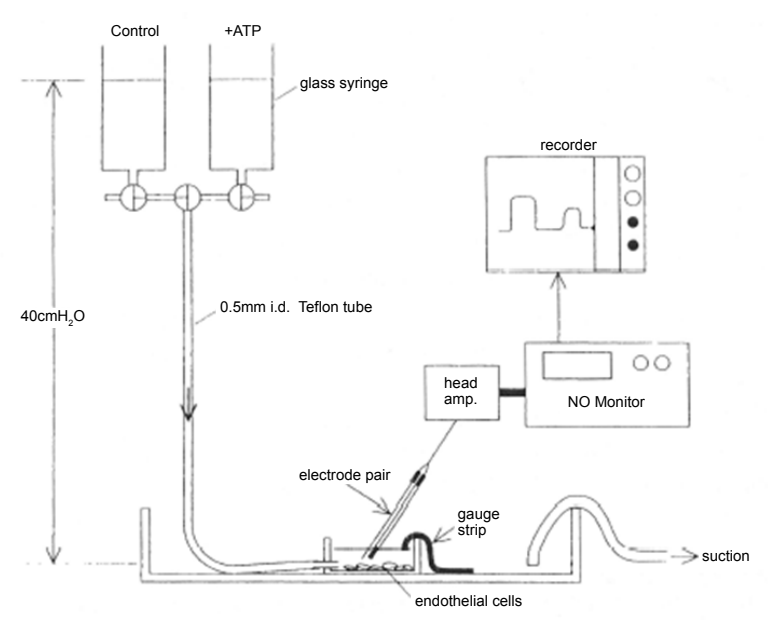

Figure 1: A perfusion system for measuring NO generated from endorhelia vells.

*Corresponding author: Hideharu Shintani, Chuo University, School of Science, 1-13-27, Kasuga Bunkyo 112-0003 Tokyo, Japan, Tel: +81425922336; E-mail: shintani@mail.hinocatv.ne.jp

Received May 20, 2013; Accepted June 17, 2013; Published June 20, 2013

Citation: Shintani H (2013) Measurements of Nitric Oxide and Peroxynitrite. Pharm Anal Acta 4: 251. doi:10.4172/2153-2435.1000251

Copyright: ( 2013 Shintani H. This is an open-access article distributed under the terms of the Creative Commons Attribution License, which permits unrestricted use, distribution, and reproduction in any medium, provided the original author and source are credited. 
Nitric oxide synthases (NOS) which produce NO in biological systems consist of three isoforms. Among these NOS-1 (neuronal type) and NOS-3 (endothelial type) transiently produce a relatively small amount of NO in response to external signalling molecules. To elucidate these transient NO responses, highly sensitive and real-time methods such as chemiluminescence methods $[3,4]$ or an electrochemical method [1] are required. On the other hand, spectrophotometric [5] and fluorimetric [6] methods are convenient for determining total NO production from NOS-2, which persistently produces a relatively large amount of NO. These methods can be applied to assay $\mathrm{NO}_{2}^{-}$, the end products of NO, accumulated in incubation media for 6 to $48 \mathrm{~h}$.

\section{Quantitation of Peroxynitrite Produced by Macrophages}

\section{Protocol}

1. Prepare Hank's balanced salt solution (HBSS) by dissolving HBSS powder (Gibco, 450-1201) and $\mathrm{NaHCO}_{3}(0.35 \mathrm{~g} / \mathrm{L})$ in doubly distilled water ( $\mathrm{pH}$ 7.4).

2. Prepare a stock solution of phorbol $\cdot 12 \cdot$ myristate- 12 acetate (PMA, Sigma; $1 \mathrm{mg} / \mathrm{mL}$ ) in DMSO. Divide into $100-\mathrm{mL}$ aliquots, and store below $-80^{\circ} \mathrm{C}$ (in the deep freeze).

3. Incubate macrophages $\left(8 \times 10^{6}\right.$ cells $\left./ \mathrm{mL}\right)$ in HBSS containing PMA (400 ng/mL), 4-hydroxyphenylacetic acid (4 • HPA • MW 152.15; $1 \mathrm{mM}$ ) and $\mathrm{Cu}, \mathrm{Zn}$-superoxide dismutase (SOD; $0.1 \mathrm{mg} / \mathrm{mL}$ ) for $4 \mathrm{~h}$ at $37^{\circ} \mathrm{C}$.

4. Centrifuge the solution (1000 $\mathrm{rpm}$ for $10 \mathrm{~min}$ ) to remove macrophages.

5. Acidify supernatant with $\mathrm{H}_{3} \mathrm{PO}_{4}(10 \%)$ and add acetonitrile (final con $z$ centration $20 \% \mathrm{v} / \mathrm{v}$ ).

6. Pass through a $0.45-\mu \mathrm{m}$ membrane filter.

7. Apply the sample to a $4.6 \mathrm{~mm} \times 150 \mathrm{~mm}$ C-18 (ODS) reversedphase HPLC column equilibrated with 20:80 (v/v) acetonitrilephosphate buffer ( $\mathrm{pH} 3.2,10 \%)$.

8. Elute the column with a linear gradient of 20 to $60 \%$ acetonitrile over $10 \mathrm{~min}$ at a flow rate of $1 \mathrm{~mL} / \mathrm{min}$.

9. Monitor UV absorption at $360 \mathrm{~nm}$ to assay 4-hydroxy-3nitrophenyl.acetic acid $\left(\mathrm{NO}_{2}-\mathrm{HPA}\right)$.

\section{Comments}

Peroxynitrite nitrates phenol derivatives in the presence of redox- active metal complexes such as $\mathrm{Fe}^{3+}$-EDTA $(1 \mathrm{mM})$ and $\mathrm{Cu}, \mathrm{Zn}$-SOD $(0.1 \mathrm{~g} / \mathrm{mL})$. Because relatively large amounts of $\mathrm{Fe}^{3+}$-EDTA have toxic side-effects and promote reactions of reactive oxygen species, $\mathrm{Cu}, \mathrm{Zn}$ SOD is used as the copper catalyst although it scavenges superoxide and might reduce peroxynitrite generation. In this method, peroxynitrite is assayed as a nitrated phenol derivative $\left(\mathrm{NO}_{2}-\mathrm{HPA}\right)$ and separated by HPLC. It has also been reported that a manganese porphyrin complex has negligible SOD activity, and is thus an excellent catalyst for this nitration reaction [7].

Peroxynitrite formation in vivo can also be estimated by measuring nitrotyrosine by means of an HPLC [8,9] or immunohistochemical [10] method. Because there are several routes for nitrotyrosine formation (for example, nitrite + peroxidase + tyrosine), nitrotyrosine itself is not such a specific indicator for peroxynitrite, although the efficiency of peroxynitrite at producing nitrotyrosine is high. Thus, control experiments with NOS inhibitors and scavengers of reactive oxygen species should be performed to determine the origin of nitrotyrosine.

\section{References}

1. Ishimori K, Ishida H, Fukahori M, Nakazawa H, Murakami1 E (1994) Practical nitric oxide measurement employing a nitric oxide-sensitive electrode. Rev Sci Instrum 65: 2714-2718

2. Murphy ME, Noack E (1994) Nitric oxide assay using hemoglobin method Methods Enzymol 233: 240-250.

3. Brien JF, McLaughlin BE, Nakatsu K, Marks GS (1991) Quantitation of nitric oxide formation from nitrovasodilator drugs by chemiluminescence analysis of headspace gas. J Pharmacol Methods 25: 19-27.

4. Kikuchi K, Nagano T, Hayakawa H, Hirata Y, Hirobe M (1993) Rea time measurement of nitric oxide produced ex vivo by luminol- $\mathrm{H} 2 \mathrm{O} 2$ chemiluminescence method. J Biol Chem 268: 23106-23110.

5. Green LC, Wagner DA, Glogowski J, Skipper PL, Wishnok JS, et al. (1982) Analysis of nitrate, nitrite, and [15N]nitrate in biological fluids. Anal Biochem 126: 131-138.

6. Misko TP, Schilling RJ, Salvemini D, Moore WM, Currie MG (1993) A fluorometric assay for the measurement of nitrite in biological samples. Anal Biochem 214: 11-16.

7. Ischiropoulos H, Zhu L, Beckman JS (1992) Peroxynitrite formation from macrophage-derived nitric oxide. Arch Biochem Biophys 298: 446-451.

8. Beckman JS, Beckman TW, Chen J, Marshall PA, Freeman BA (1990) Apparent hydroxyl radical production by peroxynitrite: implications for endothelial injury from nitric oxide and superoxide. Proc Natl Acad Sci U S A 87: 1620-1624.

9. Kaur H, Halliwell B (1994) Evidence for nitric oxide-mediated oxidative damage in chronic inflammation. Nitrotyrosine in serum and synovial fluid from rheumatoid patients. FEBS Lett 350: 9-12.

10. Ye YZ, Strong M, Huang ZQ, Beckman JS (1996) Antibodies that recognize nitrotyrosine. Methods Enzymol 269: 201-209. 